\title{
Estimation of Genetic parameters of Weekly Bodyweight and Growth Rates of Japanese quail
}

\author{
S. I. Daikwo, U. A. Dike and N. I. Dim* \\ Department of Animal production and Health, Federal University Wukari, Taraba State. Nigeria. \\ "Department of Animal Breeding and Physiology, Federal University of Agriculture Makurdi, Benue State.
} Nigeria.

\begin{abstract}
The Harvey Mixed Model Least-squares and Maximum Likelihood Computer Programme was used to estimate the heritability, genetic and phenotypic correlations of live body weight and growth rates of 684 Japanese quails. The results revealed that Japanese quails are sexually dimorphic for live body weight at all ages. Heritability of live body weight ranged from $0.12 \pm 0.02$ to $0.91 \pm 0.11$. All genetic correlation between live body weights were positive. Phenotypic correlations between live body weights at all ages were positive and very highly significant $(P<0.001)$. The heritability estimates for growth rate ranged from $0.20 \pm 0.07$ to $0.62 \pm 0.04$. Genetic correlations between growth rates ranged from -0.51 to 1.11 . Phenotypic correlations among growth rates varied from -0.02 to 0.76. It was concluded that selection for live body weight within the first two weeks of age may lead to improvement of body weight at later stages of life, and, mass selection for growth rate may lead to rapid improvement in growth rate.
\end{abstract}

Key words: Body weight, Growth rate, Heritability, Genetic correlation, Japanese quail.

\section{Introduction}

Quail breeding offers excellent opportunity for diversification and early marketing age, hence increasing activity in the production of Japanese quail in developing countries. Despite the small body size of Japanese quail, its meat and eggs are widely consumed and therefore ameliorates the problem of animal protein shortage.

The Japanese quail is a sexually dimorphic bird with females having a larger body size than males, unlike other poultry species. Sexual dimorphism is believed to evolve under the pressure of natural and sexual selection, which implies that genes controlling sexually dimorphic characteristics differ between males and females (Mignon-Grasteau et al., 2004).

Growth is the most important trait for evaluating different livestock species, especially in meat producing animals and birds. Growth traits such as bodyweight and bodyweight gain are affected by genetic and non-genetic factors and the phenomenon of growth is usually measured by observing differences in bodyweight recorded at different ages and/or bodyweight gain obtained during different growth periods (Chambers, 1993). Growth traits in the Japanese quail have been estimated by several researchers (Marks, 1993, EL-Full et al., 2001, Almeida et al., 2002, Abdel-Fattah, 2006).

The genetic parameter estimates cited in literatures for growth traits would be expected to differ in diverse genotypes and under different environments.

Therefore the objective of this study was to estimate the genetic parameters of growth traits in Japanese quail in a tropical environment like Nigerian as a step to genetic improvement.

\section{Materials And Methods}

The study was conducted at the poultry unit of the Teaching and Research Farm of the Faculty of Agriculture, Kogi State University Anyigba, Nigeria. Anyigba lies between longitudes $5^{0} 15^{1}$ and $7^{0} 45^{1}$ North and latitude $5^{0} 45^{1}$ and $8^{0} 45^{1}$ East with mean annual rainfall of $1,808 \mathrm{~mm}$. The Natural day length of Anyigba is $12-13$ hours with average monthly temperature that varies from $17^{\circ} \mathrm{C}-36.2^{\circ} \mathrm{C}$. The relative humidity varies from an average of $65-85 \%$ throughout the year (Amhakian, 2009).

The foundation stock from which the birds used for the study were hatched consisted of 90 females and 30 males maintained in the farm as separate non-pedigreed, unselected and unimproved population. A mating ratio of 1 (male) $: 3$ (females) generated 684 day old chicks in three hatches. At hatching, the chicks were leg banded with small plastic bands to indicate individual and sire identities. The chicks were brooded on a floor pen with wood shavings as litter materials. Brooding temperature started with $37.5^{\circ} \mathrm{c}$ for the first week after which the temperature was reduced by $2-3^{0} \mathrm{c}$ weekly until the end of 3 weeks of age when the birds were transferred to the rearing pens. In the rearing pens, birds were managed in deep litter from the $4^{\text {th }}$ week to 8 weeks of age using standard management procedures. Chicks were fed diet containing $24 \%$ crude protein and $2741 / \mathrm{kcal} / \mathrm{kg}$ of feed from hatch to 5 weeks of age, thereafter the birds were fed diet containing $18 \%$ crude 
protein and $2707 \mathrm{kcal} / \mathrm{kg}$ of feed as recommended by Dafwang (2006). Both feed and water were provided ad libitum.

Live bodyweight at hatch (0 week), 1-week, 2-weeks, 3-weeks, 4-weeks, 5-weeks, 6-weeks, and 7weeks of age were individually recorded to the nearest gram for all the quails using a sensitive digital electronic weighing scale. Growth rate during the periods $0-1,0-5,0-6,0-7,1-2,2-3$ and 4-5 weeks of age were calculated using the formula by Brody (1945).

$$
\text { Growth rate }=\frac{\left(\mathrm{W}_{2}-\mathrm{W}_{1}\right)}{0.5\left(\mathrm{~W}_{2}+\mathrm{W}_{1}\right)}
$$

Where, $\mathrm{W}_{1}=$ weight at the beginning of the period, $\mathrm{W}_{2}=$ weight at the end of the period.

Degree of sexual dimorphism in live weight was calculated using the formula as applied by Sezer et al. (2006).

$$
\text { Degree of sexual dimorphism }(\mathrm{DSD})=\frac{\mathrm{Fw}_{\mathrm{t}}-\mathrm{Mw}_{\mathrm{t}}}{\mathrm{F}_{\mathrm{W}}} \times \frac{100}{1}
$$

Where, $\mathrm{F}_{\mathrm{Wt}}=$ The mean female live weight at time $\mathrm{t}$

$\mathrm{M}_{\mathrm{Wt}}=$ The mean male live weight at time $\mathrm{t}$

\section{Analytical Procedures}

Data obtained on bodyweight and growth rate were analysed using the Generalized Linear Model (GLM) procedure of SPSS 14.0 (2004).

$$
\mathrm{Y}_{\mathrm{ijk}}=\mu+\mathrm{S}_{\mathrm{i}}+\mathrm{B}_{\mathrm{j}}+(\mathrm{SB})_{\mathrm{ij}}+\mathrm{e}_{\mathrm{ijk}}
$$

Where, $\mathrm{Y}_{\mathrm{ijk}}=$ Individual quail's bodyweight or growth rate of individual quail,

$\mu \quad=$ The population mean, $S_{i}=$ Effect of $\operatorname{sex}(i=1,2), B_{j}=$ Effect of the $j^{\text {th }}$ hatch $(j=1, . .3),(S B)_{i j}=$ Interaction effects of sex and hatch, $\mathrm{e}_{\mathrm{ijk}}=$ Residual random error.

The data were further subjected to genetic analysis using the mixed model least - squares and maximum likelihood computer programme of Harvey (1990). The reduced sire model (Becker, 1992) was used to fit the data.

$$
\mathrm{Y}_{\mathrm{ij}}=\mu+\mathrm{a}_{\mathrm{i}}+\mathrm{e}_{\mathrm{ij}}
$$

Where

$\mathrm{Y}_{\mathrm{ij}}=$ Observation on the $\mathrm{j}^{\text {th }}$ progeny of the $\mathrm{i}^{\text {th }}$ sire

$\mu=$ Population mean, $a_{i}=$ Random effect of the $i^{\text {th }}$ sire $(i=1, \ldots 30)$

$\mathrm{e}_{\mathrm{ij}}=$ Residual random error.

The Harvey programme computes estimates of genetic and phenotypic correlation as well as heritability estimates of traits from sire variance components.

\section{Results And Discussion}

Table 1 presents the least-square means of weekly body weight and degree or sexual dimorphism in Japanese quail. Regardless of sex, the mean bodyweights remarkably increased as the quails progressed in age. The female chicks were significantly $(\mathrm{P}<0.05)$ heavier in body weight than the males. The degree of sexual dimorphism estimates were $3.23,3.73,5.26,3.58,3.93,5.54,10.78$ and $11.48 \%$ at $0,1,2,3,4,5,6$ and 7 weeks of age. Sexual dimorphism tend to increase with increase in age.

The bodyweight at hatch obtained in this study is in agreement with Abdel-Fattah (2006) and AbdelTawab (2006) who reported values that ranged between 6.0 and 9.3g. Bodyweight at 1, 2, 3, 4, 5, 6 and 7 weeks of age were lower than those reported by El-Full et al. (2001), Abdel-Fattah (2006) and Abdel-Tawab (2006). The observed differences between the various estimates reported at particular ages could be due to the differences in climate and managerial conditions under which different flocks were reared and to the possible differences in genetic make-up of the different flocks or to the differences in the statistical manipulation of the data used to obtain the estimates. Female quails were significantly $(\mathrm{P}<0.05)$ heavier than the males from 0 (hatch) week of age up to 7 weeks of age. This observation is similar to those of Soltan et al. (1987), Oguz et al. (1996) and Abdel-Fattah (2006). The degree of sexual dimorphism (DSD) reported in this study follow the same trend with results presented by Hort et al. (1999) and Sezer et al. (2006). The occurrence of sexual dimorphism in the Japanese quail indicates potentials for their possible development as sire and dam lines in breed development.

Table 2 shows the means of growth rates during the different growth periods in Japanese quail. The growth rates in the different growth periods studied (0-1, 0-5, 0-6, 0-7, 1-2, 2-3 and 4-5 weeks) for combined sexes were $0.63 \pm 0.01,1.74 \pm 0.02,1.78 \pm 0.02,2.27 \pm 0.47,0.69 \pm 0.01,0.61 \pm 0.01$ and $0.29 \pm 0.01$, respectively. 
Differences in growth rates between the two sexes which favoured the females agree with the findings of Marks (1978) and Aboul-Hassan (2000) who reported that females had higher growth rates than males during the different growth periods from hatch up to 6 weeks of age. The values of growth rates obtained in this study differed from the reports of El-Full et al. (2001), Aboul-Hassan (2000) and Abdel-Fattah et al. (2006). The differences could have been caused by both genetic and non-genetic factors. It seems that growth rate in the males and females of Japanese quail should be considered distinct characteristics of population as reported by Sefton and Siegel (1974). This fact should be taken into account in any breeding programme aimed at improving growth characteristics in Japanese quail.

Heritability from sire variance component, genetic correlation and phenotypic correlation among bodyweights at different ages in Japanese quail are presented in Table 3. Heritability estimates ranged from $0.12 \pm 0.02$ at 6 weeks of age to $0.91 \pm 0.11$ at 0 week (hatch) of age. All genetic correlation estimates between bodyweights at different ages were positive. The genetic correlation estimates of body weight ranged from 0.18 to 1.17. There were cases when genetic correlation estimates were outside parametric range (1.01, 1.05 and 1.17, respectively). Generally, phenotypic correlation between bodyweights at all ages were positive and very highly significant $(\mathrm{P}<0.001)$.

The heritability of body weight at hatch is in close agreement with the value reported by El-Fiky (1991). The heritability estimate of 4-week body weight in this study generally fall within the range of 0.17 0.60 reported by Bahie El-Deen (1994) for Japanese quail. Heritability tends to reduce with age. This similar observation was earlier reported by Saatei et al. (2002) for Japanese quail also. The moderate to high heritabilities reported indicate that response to selection at 7, 4, 3, 2, 1 and 0 weeks of age could be rapid while the low heritabilities implies that response to selection at the $5^{\text {th }}$ and $6^{\text {th }}$ week of age could be slow. This slow growth may mean that the genes for growth rate had started to switch off or that at this age feed had started to be used for sexual maturity and reproduction.

The genetic and phenotypic correlation estimates between body weights at different ages were similar in magnitude and direction. Similar trends were reported by Sharaf (1992), Farahat (1998) and Shalan (1998). Genetic correlations greater than 1 obtained between bodyweights at some ages in this study were outside parametric range. El-Full et. al. (2001) who used 3,150 birds also estimated genetic correlations among some growth traits with values greater than 1, in Japanese quail in Egypt. Problems associated with small group data size, sampling errors and data inbalance (unequal group sizes) could indicate very high genetic correlations between traits involved, which sometimes can be outside the parametric range. The strong and positive genetic relationships between bodyweights at different ages could be attributed to pleitropic and linkage effect of genes. This means that the same genes were controlling the body weight traits at different ages with increasing expressivity.

The heritability estimates from sire variance component, genetic and phenotypic correlations among growth rates in Japanese quail are shown in Table 4. The estimates of heritability for growth rate ranged from $0.20 \pm 0.07$ at $1-2$ weeks to $0.62 \pm 0.04$ at $0-5$ weeks of age. Growth rate during the period from $0-1$ week of age had significant negative genetic correlation with growth rates at 0-5, 0-6, 0-7, 1-2, 2-3, and 4-5 weeks of age. The genetic correlation between 1-2 weeks and 4-5 weeks growth rates was low $(0.05)$ and positive. Genetic correlations between growth rates during other periods studied were positive and moderate to high in the range of 0.38 to 1.11 . The phenotypic correlation among growth rates ranged from -0.02 between $0-7$ and $4-5$ weeks growth period to 0.76 between $0-5$ and $0-6$ weeks growth period.

The heritability estimates of growth rates obtained in this study were moderate to high and above the values reported by Aboul-Hassan (2000) and El-Full et al. (2001) for Japanese quail. The results indicate that selection for this trait might result in appreciable improvement. Since growth rates during the periods from $0-5$ weeks and 0-6 weeks had the highest heritabilities, they can be used as criteria of selection to improve growth performance of Japanese quails. Most of the genetic correlations, especially among growth rates separated by several weeks were high. Lower values tended to involve growth rates taken only a week apart. This results are in agreement with the findings of Chambers (1993) for chickens and El-Full et al. (2001) for Japanese quail. Most of the genetic and phenotypic correlations among the growth rates studied were positive, which indicates that they can be simultaneously improved while the negatively related ones show that improving one might be at the detriment of the other.

\section{Conclusion}

On the basis of heritability estimates obtained for bodyweights at various ages, selection for body weight can start within the first two weeks of age due to high body weight heritability at this age. The low to moderate heritability of body weight at older ages may indicate that environmental effects were more important in influencing body weight at these ages than additive genetic effects. Greater attention should therefore be paid to optimal conditions of feeding and management at these stages. Mass selection for rate of growth in Japanese quails may lead to rapid improvement in growth rate due to the moderate to high heritability indicated for 
growth rate in this study. The high and positive genetic correlation observed between body weights at different ages revealed the same quantitative traits loci (QTL) acting to express body weight at different ages. Selection for body weight at early stages of life would lead to improvement of body weight at later stages of life in the Japanese quail.

\section{References}

[1]. Abdel-Fattah, M.H. (2006). Selection for increased bodyweight and growth rate in Japanese quail. Ph.D Thesis, Fac. Agric. Fayoum Univ. Egypt. 153 pp.

[2]. Abdel-Fattah, M.H., El-Full, E.A., Farahat, G.S., Hataba, N.A and Khalifa, M.A (2006). Inheritance of body weight, Growth rate and fitness traits in Japanese quail. Egypt. Poult. Sci. J. 26(3): 1195-1215.

[3]. Abdel-Tawab, S.K. (2006). The effect of selection for egg weight on some productive traits in Japanese quail. M.Sc Thesis, Fac. Agric. Al-Azhar Univ. Cairo, Egypt 66pp.

[4]. Aboul-Hassan, M.A. (2000). Comparative study of growth traits in two strains of Japanese quail. Fayoum J. Agric. Res. Dev. 14:189-197.

[5]. Almeida, M. I., Oliveira, E. G., Ramos, P. R., Veiga, P. R., and Dias, K. (2002). Growth performance of meat male quails of two lines under two nutritional environments. Arch. of Vet. Sci. 7(2): 103-108.

[6]. Amhakian, S.O. (2009). Evaluation of phosphorus status of some soils in Kogi State Nigeria. Ph.D Thesis, Edo State Univ. Ekpoma, Nigeria. 161pp.

[7]. Bahie El-Deen, M. (1994). Selection indices and crossing as a tool for improving meatand egg production in Japanese quail. Ph. D Thesis Fac. Agric. Alexandria Univ. Egypt. 138pp.

[8]. Becker, W. A. (1992). Manual of Quantitative Genetics. $5^{\text {th }}$ Edition USA, Academic enterprise Pullman, 189pp.

[9]. Brody, S. (1945). Bioenergetics and growth. Reinhold pub. Corp., New York, N. T.,

[10]. Chambers, J. R. (1993). Genetics of growth and meat production in chickens. In: Poultry breeding and genetics (Ed: Crawford, R.D.). Elsevier Sci. Pub. Pp. 599-644.

[11]. Dafwang, I. I. (2006). Nutrient requirements and feeding regiment in quail production. A paper presented at National workshop on quail production for sustainable household protein intake. NAERLS, Ahmadu Bello University Zaria. Sept. 11-13. pp 12-19.

[12]. El-Fiky, F.A. (1991). Genetic studies on some economic traits in Japanese quail. Ph.D. Thesis, Fac. Agric. Al-Azhar Univ. Cairo, Egypt. 156pp.

[13]. El-Full, E.A., Ali, A.A., El-Fattah, A. and Khalifa, M. A. (2001). Inheritance of some growth characteristics of Japanese quail. Egypt. Poult. Sci. J. 21(3): 719-739.

[14]. Farahat, G.S. (1998). Estimation of some genetic and phenotypic parameters for growth and reproductive traits of Japanese quail. M.Sc. Thesis, Fac. Agric. Fayoum, Cairo Univ. Egypt. 98pp.

[15]. Harvey, W.R. (1990). Mixed model least-squares and maximum likelihood computer programme. Ohio State Univ. Columbus (Mimeo).

[16]. Hort, J., Hyankova, L. and Knizetova, H. (1999). The role of sexual dimorplism in the onset of egg-laying in Japanese quail. Proc. Poult. Genetics Symp. Oct. 6-8, Marience, Germany. Pp.120.

[17]. Marks, H. L. (1978). Compensatory growth in Japanese quail following protein restriction. Poult. Sci. J. 57:1473-1477

[18]. Marks, H. L. (1993). Carcass composition, feed intake and feed efficiency following long-term selection for 4-week bodyweight in Japanese quail. Poult. Sci. J. 72:1005-1011.

[19]. Mignon-Grasteau, S., David, J., Gilbert, P., Legout, H., Petavy, G., Moreteau, B. and Beaumont, C. (2004). REML estimates of genetic parameters of sexual dimorphism for wing and thorax length in Drosophila melanogaster. J. Genet. 83:163-170.

[20]. Oguz, I., Ahan, O., Kirkpinar, F. and Setter, P. (1996). Body weights, carcass characteristics, organ weights, abdominal fat and lipid content of Liver and carcass in two lines of Japanese quail, unselected and selected for 4-week bodyweight. Brit. Poult. Sci. J. 37:579-588.

[21]. Saatei, M., Dewi, I., Aksoy, R., Kirmizibayrak, T. and Ulutas, Z. (2002). Estimation of genetic parameters for weekly live weight in one to one sire and dam pedigree recorded Japanese quail. In: $7^{\text {th }}$ world congress on Genetic applied to livestock prod. Paris, France. P-20.

[22]. Sefton, A.E. and Siegel, P. B. (1974). Inheritance of body weight in Japanese quail. Poult. Sci. J. 53:1597-1603.

[23]. Sezer, M., Berberoglu, E. and Ulutas, Z. (2006). Genetic association between sexual maturity and weekly live weights in layingtype Japanese quail. South African J. Anim. Sci. 36(2): 142-148.

[24]. Shalan, H. M. (1998). Independent culling levels, selection and crossing for improving meat and egg production in Japanese quail. Ph. D. Thesis, Fac. Agric. Alexandria Univ., Egypt. 133pp.

[25]. Sharaf, M. M.. (1992). Genetic and non-genetic estimates of some reproductive and productive traits in Japanese quail. Egypt. Poult. Sci. J. 12:211-231.

[26]. Soltan, M. E., El-Sayed, M. A. and Abou-Ashour, A.M. (1987). Development of European quail under Egyptian conditions. I-Early response to selection for bodyweight at four weeks of age. Minufiya J. Agric. Res. 11:1-20.

[27]. SPSS (2004). Statistical package for social sciences. Release 14.0 for Windows. IL 60611. Chicago. 
Table 1: Least-squares Means \pm SEM for weekly body weight and degree of sexual dimorphism (DSD, \%) in Japanese quail.

\begin{tabular}{|c|c|c|c|}
\hline Age (weeks) & Sex & Body weight (g) & DSD (\%) \\
\hline \multirow{2}{*}{$\mathrm{O}$ (Hatch) } & Male & $6.60 \pm 0.07^{\mathrm{b}}$ & \\
\hline & Female & $6.82 \pm 0.08^{\mathrm{a}}$ & 3.23 \\
\hline \multirow[t]{2}{*}{1} & Male & $13.42 \pm 0.19^{\mathrm{b}}$ & \\
\hline & Female & $13.94 \pm 0.20^{\mathrm{a}}$ & 3.73 \\
\hline \multirow[t]{2}{*}{2} & Male & $27.74 \pm 0.44^{\mathrm{b}}$ & \\
\hline & Female & $29.28 \pm 0.46^{\mathrm{a}}$ & 5.26 \\
\hline \multirow[t]{2}{*}{3} & Male & $50.93 \pm 0.76^{\mathrm{b}}$ & \\
\hline & Female & $52.82 \pm 0.80^{\mathrm{a}}$ & 3.58 \\
\hline \multirow[t]{2}{*}{4} & Male & $72.11 \pm 0.92^{\mathrm{b}}$ & \\
\hline & Female & $75 \pm 06.097^{\mathrm{a}}$ & 3.93 \\
\hline \multirow[t]{2}{*}{5} & Male & $95.95 \pm 1.05^{\mathrm{b}}$ & \\
\hline & Female & $101.58 \pm 1.10^{\mathrm{a}}$ & 5.45 \\
\hline \multirow[t]{2}{*}{6} & Male & $117.39 \pm 1.13^{\mathrm{b}}$ & \\
\hline & Female & $131.58 \pm 1.19^{\mathrm{a}}$ & 10.78 \\
\hline \multirow[t]{2}{*}{7} & Male & $124.49 \pm 1.11^{\mathrm{b}}$ & \\
\hline & Female & $14064+116^{\mathrm{a}}$ & 1148 \\
\hline
\end{tabular}

$a, b=$ Means within sex-subgroup with different superscripts are significantly different $(\mathrm{P}<0.05)$ $\mathrm{DSD}=$ Degree of sexual dimorphism

Table 2: Means \pm SEM for growth rates at different ages in Japanese quail.

\begin{tabular}{llll}
\hline Periods & Male & Female & Combined sexes \\
\hline $0-1$ week & $0.62 \pm 0.01$ & $0.63 \pm 0.01$ & $0.63 \pm 0.01$ \\
$0-5$ week & $1.73 \pm 0.03$ & $1.74 \pm 0.03$ & $1.74 \pm 0.02$ \\
$0-6$ week & $1.78 \pm 0.03$ & $1.79 \pm 0.03$ & $1.78 \pm 0.02$ \\
$0-7$ week & $1.81 \pm 0.82$ & $2.73 \pm 0.78$ & $2.27 \pm 0.47$ \\
$1-2$ week & $1.68 \pm 0.01$ & $0.71 \pm 0.01$ & $0.69 \pm 0.01$ \\
$2-3$ week & $0.60 \pm 0.01$ & $0.62 \pm 0.01$ & $0.61 \pm 0.01$ \\
$4-5$ week & $0.29 \pm 0.01$ & $0.30 \pm 0.01$ & $0.29 \pm 0.01$ \\
\hline
\end{tabular}


Estimation of Genetic parameters of Weekly Bodyweight and Growth Rates of Japanese Quail.

Table 3: Heritability from sire variance component (on Diagonal), Genetic correlation (above diagonal) and phenotypic correlation (below diagonal) among body weights at different Ages in Japanese quail.

\begin{tabular}{|c|c|c|c|c|c|c|c|c|}
\hline & $\begin{array}{l}\text { O } \\
\text { week } \\
\end{array}$ & $\begin{array}{l}1 \\
\text { week }\end{array}$ & $\begin{array}{l}2 \\
\text { week }\end{array}$ & $\begin{array}{l}3 \\
\text { week }\end{array}$ & $\begin{array}{l}4 \\
\text { week }\end{array}$ & $\begin{array}{l}5 \\
\text { week } \\
\end{array}$ & $\begin{array}{l}6 \\
\text { week } \\
\end{array}$ & $\begin{array}{l}7 \\
\text { week } \\
\end{array}$ \\
\hline $\begin{array}{l}\mathrm{O} \\
\text { week }\end{array}$ & $0.91 \pm 0.11$ & 0.74 & 0.59 & 0.90 & 0.81 & 0.80 & 0.38 & 0.40 \\
\hline $\begin{array}{l}1 \\
\text { week }\end{array}$ & $0.66^{* * *}$ & $0.88 \pm 0.27$ & 0.93 & 0.82 & 0.75 & 0.89 & 0.72 & 0.23 \\
\hline $\begin{array}{l}2 \\
\text { Week }\end{array}$ & $0.61^{* * *}$ & $0.82^{* * *}$ & $0.50 \pm 0.02$ & 0.85 & 0.97 & 1.17 & 0.92 & 0.61 \\
\hline $\begin{array}{l}3 \\
\text { week }\end{array}$ & $0.47^{* * *}$ & $0.47^{* * *}$ & $0.69^{* * *}$ & $0.32 \pm 0.19$ & 0.94 & 0.98 & 0.67 & 0.37 \\
\hline $\begin{array}{l}4 \\
\text { week }\end{array}$ & $0.46^{* * *}$ & $0.52^{* * *}$ & $0.72^{* * * *}$ & $0.92^{* * *}$ & $0.27 \pm 0.18$ & 1.05 & 1.01 & 0.66 \\
\hline $\begin{array}{l}5 \\
\text { week }\end{array}$ & $0.46^{* * *}$ & $0.47^{* * *}$ & $0.65^{* * *}$ & $0.79^{* * *}$ & $0.87^{* * *}$ & $0.18 \pm 0.06$ & 0.95 & 0.34 \\
\hline $\begin{array}{l}6 \\
\text { week }\end{array}$ & $0.30^{* * * *}$ & $0.35^{* * *}$ & $0.51^{* * *}$ & $0.60^{* * *}$ & $0.68^{* * *}$ & $0.79^{* * *}$ & $0.12 \pm 0.02$ & 0.18 \\
\hline $\begin{array}{l}7 \\
\text { week }\end{array}$ & $0.19^{* * * *}$ & $0.13^{* * *}$ & $0.28^{* * *}$ & $0.43^{* * *}$ & $0.49^{* * *}$ & $0.59^{* * * *}$ & $0.83^{* * *}$ & $0.21 \pm 0.06$ \\
\hline
\end{tabular}

$* * *=(\mathrm{P}<0.001)$ 
Estimation of Genetic parameters of Weekly Bodyweight and Growth Rates of Japanese Quail.

Table 4: Heritability from sire variance component (on Diagonal), Genetic correlation (above diagonal) and phenotypic correlation (below diagonal) among growth rates in Japanese quail.

\begin{tabular}{|c|c|c|c|c|c|c|c|}
\hline & $\begin{array}{l}0-1 \\
\text { week }\end{array}$ & $\begin{array}{l}0-5 \\
\text { week }\end{array}$ & $\begin{array}{l}0-6 \\
\text { week }\end{array}$ & $\begin{array}{l}0-7 \\
\text { week }\end{array}$ & $\begin{array}{l}1-2 \\
\text { week }\end{array}$ & $\begin{array}{l}2-3 \\
\text { week }\end{array}$ & $\begin{array}{l}4-5 \\
\text { week }\end{array}$ \\
\hline $\begin{array}{l}0-1 \\
\text { week }\end{array}$ & $0.32 \pm 0.09$ & -0.72 & -0.62 & -0.51 & -0.61 & -0.98 & -0.41 \\
\hline $\begin{array}{l}0-5 \\
\text { week }\end{array}$ & $0.22^{* * *}$ & $0.62 \pm 0.04$ & 0.88 & 0.90 & 0.98 & 0.84 & 0.38 \\
\hline $\begin{array}{l}0-6 \\
\text { week }\end{array}$ & $0.13^{*}$ & $0.76^{* * *}$ & $0.48 \pm 0.01$ & 0.73 & 1.08 & 0.90 & 0.44 \\
\hline $\begin{array}{l}0-7 \\
\text { week }\end{array}$ & -0.04 & 0.02 & 0.02 & $0.36 \pm 0.01$ & 0.75 & 0.93 & 0.59 \\
\hline $\begin{array}{l}1-2 \\
\text { week }\end{array}$ & $-0.30^{* * * *}$ & $0.34^{* * *}$ & $0.24^{* * *}$ & $-0.11^{*}$ & $0.20 \pm 0.07$ & 1.11 & 0.05 \\
\hline $\begin{array}{l}2-3 \\
\text { week }\end{array}$ & $-0.53^{* * *}$ & $0.29^{* * * *}$ & $0.25^{* * *}$ & $-0.17^{* * *}$ & -0.03 & $0.40 \pm 0.02$ & 0.43 \\
\hline $\begin{array}{l}4-5 \\
\text { week }\end{array}$ & $-0.14^{* *}$ & 0.10 & $0.14^{* * *}$ & -0.02 & $-0.17^{* *}$ & $-0.10^{*}$ & $0.28 \pm 0.08$ \\
\hline
\end{tabular}

$*=(\mathrm{P}<0.05) \quad * *=(\mathrm{P}<0.01) \quad * * *(\mathrm{P}<0.001)$ 